perhaps completed in vitro holds hope that in future experiments its nature may be explored.
R. V. Petrov
L. S. Sestavina
E. I. Pantelejev

Institute of Biophysics,

Ministry of Public Health of USSR,

Moscow.

Received October 20, 1967; revised January 2, 1968

1 Sehwarz, M. R., Immunology, 10, 281 (1965).

S Festenstein H. Ann NY Acad. Sci, 129, 567 (1966).

' Hellström, K. E., Hellström, I., and Bergheden, C., Nature, 208, 458 (1965).

4 Petrov, R. V., and Seslavina, L. S., Rep. Acad. Sci., USSR, 176, 1170 (1987)

- Jerne, N. K., and Nordin, A. A., Science, 140, 405 (1963).

- TIIll, J. E., and MacCulloch. F. A., Rad. Res., 14, 213 (1961).

\section{Use of Horse Anti-pig Leucocyte Serum to suppress the Homograft Reaction in Pigs}

INTEREST in the use of heterologous anti-leucocyte serum as a means of suppressing the homograft reaction was stimulated by the work of Woodruff and Anderson ${ }^{1,2}$, who showed that rejection of skin allografts in rats could be delayed by administering rabbit anti-rat leucocyte serum to the skin graft recipients. Similar findings pertaining to allografts of skin in mice have since been reported by Monaco et al..$^{3}$ and Levey and Medawar ${ }^{4}$.

This communication reports preliminary observations on the value of horse anti-pig leucocyte serum in suppressing the rejection of skin allografts in pigs.

Two horses were immunized with a cell suspension in Medium 199 (Glaxo) obtained by gently grinding fragments from the mesenteric lymph nodes of outbred pigs, using a hand operated glass piston blender. The cell suspension was washed by centrifugation at $580 \mathrm{~g}$ for $5 \mathrm{~min}$ and resuspended in fresh Medium 199. made larger, 1 in. $^{2}$, to facilitate the recognition of early thickening.

The pigs were divided into four groups (Table 1). Pigs of group 1 were untreated controls in which the skin allografts were allowed to reject naturally. Pigs of group 2 received $3.0 \mathrm{ml} . / \mathrm{kg}$ body weight of normal horse serum by intravenous injection daily, commencing on the day of skin grafting. Pigs of groups 3 and 4 received $0.75 \mathrm{ml}$. or $1.5 \mathrm{ml} . / \mathrm{kg}$ body weight of horse anti-pig, anti-leucocyte serum daily by intravenous injection, commencing on the day of skin grafting. In all animals of groups 2,3 and 4, administration of serum was continued until graft rejection was judged to be complete.

All skin grafts were examined, without previous knowledge of the origin of a particular graft, at 2 day intervals, starting on day 5 after skin grafting. Skin graft rejection was considered to have commenced on the first day that a graft was palpably thickened. It proved difficult to assess the time of complete rejection on account of the thickness of pig skin.

The times in days to the commencement of skin allograft rejection are shown in Table 1 . It may be seen that normal horse serum, group 2, or the lower dose of horse anti-pig leucocyte serum, group 3 , had no influence on the time of skin allograft rejection. In a dose of $1.5 \mathrm{ml} . / \mathrm{kg}$ body weight/day, however, the anti-leucocyte serum produced a striking delay in the commencement of skin allograft rejection.

Necropsies were performed on all the pigs between the twenty-first and twenty-eighth days. No differences were observed with the naked eye or histologically between the lymph nodes of the groups given anti-leucocyte serum and the control groups. All contained a normal amount of lymphoid tissue with normal germinal centres. The lymph nodes which drained the graft areas were histologically similar to the other lymph nodes. The spleens were also normal, and no abnormalities were seen in the kidneys by conventional staining and light microscopy.

The results indicate that it is possible to obtain a marked prolongation of skin allograft survival without serious toxicity. It would be interesting to determine whether

Table 1. TIME, IN DAYS, TO OOMMENCEMENT OF SKIN AILOORAFT REJECTION IN UNTREATED PIGS AND PIGS REOETVTKG NORMAI HORBE OR HORSE ANTI-PIG LEUCOCYTE SERUM

\section{Category}

No treatment (group 1: two pigs)

Normal horse serum (group 2: two pigs)

Anti-leucocyte serum (group 3: two pigs)

Group 4: two pigs

$3.0 \mathrm{ml} . \mathrm{kg}$ body weight/day, intravenously

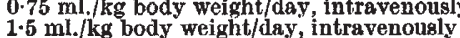

* Recelved ALS from horse 1. The other pigs in groups 3 and 4 received ALS from horse 2.

Tean

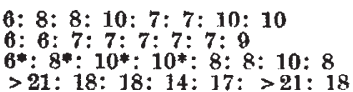

Mean
$8 \cdot 3$
$7 \cdot 0$
8.5

$>18 \cdot 1$
Horse 1 received three intravenous injections, each of $1 \times 10^{8}$ cells, at intervals of 7 days, and 4 l. of whole blood was taken from it 7 days later. After a further 24 days the horse was given another injection of $0.44 \times 10^{\circ}$ lymph node cells and a further 3.5 1 . of blood was taken 7 days later.

Horse 2 received three intravenous injections at intervals of 7 days, the injections being of $1 \times 10^{9}, 1.7 \times 10^{8}$ and $1.86 \times 10^{9}$ cells. This horse was bled to give $5.0 \mathrm{l}$. of blood after a further 7 days.

The blood was allowed to stand at room temperature for approximately $2 \mathrm{~h}$ and was then stored overnight at $4^{\circ} \mathrm{C}$. The serum was separated after centrifugation at $1,800 \mathrm{~g}$ for $10 \mathrm{~min}$ and absorbed, using one-third of its volume of packed pig erythrocytes, at $37^{\circ} \mathrm{C}$ for $1 \mathrm{~h}$ and then overnight at $4^{\circ} \mathrm{C}$. The serum was again separated after centrifugation at $1,800 \mathrm{~g}$ for $10 \mathrm{~min}$, sterilized by Seitz filtration and stored at $-20^{\circ} \mathrm{C}$.

Normal horse serum was obtained by bleeding a non. immunized horse and processed as before except that absorption against pig erythrocytes was omitted.

Each pig studied received two skin autografts and four skin allografts. Skin grafting was carried out as described by Jaffe et al. ${ }^{5}$ with the exception that the grafts were a still greater delay in skin graft rejection could be produced by larger daily doses of anti-leucocyte serum, or by a single massive injection of the anti-serum on the day of skin grafting.

We thank A. Addicott, F. E. Badrick, P. W. Davies, R. Hill, A. Medlen and G. W. Sweetnam for assistance.

Department of Veterinary Surgery,

$$
\text { J. N. LUCRE }
$$

\section{E. J. IMMELMAN}

M. O. SYMES

Department of Surgery,

\section{A. C. HoNT}

Department of Pathology,

University of Bristol.

Received November 6, 1967; revised January 3, 1968 .

${ }^{2}$ Woodruff, M. F. A., and Anderson, N. F., Nature, 200, 702 (1968).

Woodruff, M. F. A., and Anderson, N. F., Ann. NY Acad. Sei., 120, 119 (1964).

Monaco, A. P.. Wood, M. L., Gray. J. G., and Russell, P. S., J. Immunol., 96, $229(1965)$.

- Levey, R. H., and Medawar, P. B., Ann. NY Acad. Sci.. 129, 164 (1960).

- Jaffe, W. P. Symes, M. O., and Terblanche, J., in The Liver (edit. by Read, P. E.), Colston Papers, 19 (Butterworth, In The Liver (edit. by
Ren, in the press). 